\title{
Wyzwania systemowe stojące przed hematologią onkologiczną w aspekcie starzejącego się społeczeństwa w Polsce
}

\author{
Systemic challenges facing the hematological oncology \\ in the context of an aging population in Poland
}

\author{
Jakub Gierczyński1, 4, Ewa Lech-Marańda ${ }^{2,3}$, Małgorzata Gałązka-Sobotka ${ }^{4}$, \\ Jerzy Gryglewicz ${ }^{4}$, Joanna Didkowska ${ }^{5}$, Urszula Wojciechowska ${ }^{5}$, Krzysztof Warzocha ${ }^{2}$ \\ ${ }^{1}$ Katedra Polityki Ochrony Zdrowia, Uniwersytet Medyczny, Łódź \\ ${ }^{2}$ Klinika Hematologii, Instytut Hematologii i Transfuzjologii, Warszawa \\ ${ }^{3}$ Klinika Hematologii i Transfuzjologii, Centrum Medyczne Kształcenia Podyplomowego, Warszawa \\ ${ }^{4}$ Instytut Zarządzania w Ochronie Zdrowia (IZWOZ), Uczelnia Łazarskiego, Warszawa \\ ${ }^{5}$ Centrum Onkologii, Krajowy Rejestr Nowotworów, Warszawa
}

\begin{abstract}
Streszczenie
Starzenie sie spoteczeństwa i wzrastajaca zapadalność na nowotwory hematologiczne jest wyzwaniem dla systemu ochrony zdrowia. Nowotwory hematologiczne stanowity okoto $5 \%$ wszystkich zachorowań na nowotwory ogótem $w 2012$ roku, a potowa chorych miata ponad 65 lat. Nowe standardy leczenia oraz technologie medyczne stwarzaja szanse dla chorych, ale ich zastosowanie wymaga wnikliwych badan oraz potwierdzenia użteczności $w$ ramach praktyki klinicznej. Warunkami adekwatnego dostępu pacjentów $w$ Polsce do technologii medycznych $w$ ramach aktualnych standardów terapeutycznych sq optymalizacja i adekwatne finansowanie systemu opieki zdrowotnej. Wydaje się, że hematologia onkologiczna może być modelowym przyktadem efektywnych rozwiazań systemowych — z pacjentem jako podmiotem tego systemu.
\end{abstract}

Słowa kluczowe: starzenie się, zachorowalność, standardy terapeutyczne, nowe technologie medyczne, programy lekowe, model opieki onkohematologicznej

Hematologia 2015; 6, 3: 293-300

\begin{abstract}
The aging population and the increasing incidence of hematological malignancies is a challenge for the health care system in Poland. New medical technologies offer opportunities for patients above 65 years of age. Their use, however, requires careful research and confirm their usefulness in the context of current therapeutic guidelines. The requirement for patient access to modern medical technologies is to optimize operations and adequate funding of the healthcare system. It appears that the area of oncological hematology can be a model for effective solutions to the system, with the patient, as the subject of the system.
\end{abstract}

Key words: aging, morbidity, therapeutic standards, new medical technologies, drug programs, model of onco-hematological care

Hematologia 2015; 6, 3: 293-300

Adres do korespondencji: Jakub Gierczyński, Instytut Zarządzania w Ochronie Zdrowia, Uczelnia Łazarskiego, ul. Świeradowska 43, 02-662 Warszawa, tel. 225435 351, faks 225435 350, e-mail: j.gierczynski@lazarski.edu.pl 


\section{Wprowadzenie}

Starzenie się społeczeństwa i związana $z$ nim coraz większa zapadalność na nowotwory hematologiczne jest wyzwaniem dla systemu ochrony zdrowia w Polsce. W pracy poddano analizie skalę zjawiska, możliwości terapeutyczne oraz pożądane zmiany w systemie ochrony zdrowia, które mogłyby doprowadzić do zwiększenia dostępności świadczeń finansowanych publicznie dla pacjenta w Polsce. Publikowane nowe standardy terapeutyczne oraz rejestrowane nowe technologie medyczne stwarzają szanse dla chorych, ale ich stosowanie wymaga wnikliwych badań oraz potwierdzenia użyteczności w ramach praktyki klinicznej. Wydaje się również, $\dot{z}$ e hematologia onkologiczna, ze względu na skale epidemiologiczną problemu, może być modelowym przykładem efektywnych rozwiązań systemowych $-z$ pacjentem jako podmiotem tego systemu.

\section{Starzenie się społeczeństwa} w kontekście zachorowalności na nowotwory hematologiczne

Starzenie się społeczeństwa jest zjawiskiem powszechnym w całej Europie. Zgodnie $z$ definicją starzenie się populacji oznacza zwiększanie odsetka osób starszych przy jednoczesnym zmniejszaniu odsetka dzieci. W piśmiennictwie jako metrykalny próg starości przyjmuje się najczęściej 60. (World Health Organization) lub 65. rok życia (ONZ [Organizacja Narodów Zjednoczonych [ONZ], Eurostat). Istnieje wiele miar i klasyfikacji stopnia zaawansowania starzenia społeczeństwa. Zgodnie $z$ kryterium ONZ za starą uznaje się populację, w której udział ludności w wieku 65 lat i więcej przekracza $7 \%$. Odsetek powyżej $10 \%$ oznacza fazę zaawansowanej starości [1].

Prognozy demograficzne dla Polski wskazują, że w najbliższych latach proces starzenia się populacji będzie narastał. W 2013 roku liczba osób w wieku 65 lat i więcej $(65+)$ wynosiła $5,7 \mathrm{mln}$, tj. $14,7 \%$ populacji, a w 2035 roku liczba ta wyniesie $8,35 \mathrm{mln}$, co będzie stanowiło $23 \%$ populacji. W 2050 roku osoby w wieku $65+$ będą stanowiły $30 \%$ populacji, a ich liczba wyniesie $11 \mathrm{mln}$. Zgodnie $z$ przyjętymi założeniami $\mathrm{w}$ okresie objętym prognozą przeciętne trwanie życia będzie się nadal wydłużało, osiągając w 2050 roku wartości większe od obecnie notowanych o 9 lat w przypadku mężczyzn i 6 lat w przypadku kobiet [1].

Starzenie się populacji Polski stawia wiele wyzwań przede wszystkim przed systemem opieki zdrowotnej, w tym onkologicznej i onkohematolo- gicznej. Według danych Krajowego Rejestru Nowotworów (KRN) liczba zachorowań na nowotwory złośliwe w Polsce w ostatnich trzech dekadach wrosła ponad 2-krotnie - do 152,9 tys. przypadków w 2012 roku, w tym liczba zarejestrowanych w KRN nowotworów hematologicznych (C81-C96) wyniosła 8364 [2]. Nowotwory hematologiczne stanowity więc $5,47 \%$ wszystkich zachorowań na nowotwory w 2012 roku. Należy jednocześnie zaznaczyć, że dane publikowane przez KRN są niedoszacowane na poziomie około $15 \%$.

Prognozy zachorowań na nowotwory na najbliższe dekady wykazują trend wzrostowy, szczególnie w grupie wiekowej po 65. roku życia [3]. Dotyczy to przede wszystkim hematologii onkologicznej, ponieważ zapadalność na nowotwory układów krwiotwórczego i chłonnego zwiększa się $z$ wiekiem, a Polacy żyją coraz dłużej. Należy również podkreślić, że występowanie nowotworów hematologicznych $\mathrm{w}$ wieku senioralnym nie zależy od czynników ryzyka wynikających ze stylu życia.

Według danych KRN w latach 2008-2012 chorzy w wieku powyżej 65 lat stanowili około $50 \%$ wszystkich chorych na nowotwory hematologiczne. W 2008 roku odsetek ten stanowił 47\%, w 2009 roku $-47,56 \%$, w 2010 roku $-48 \%$, w 2011 roku $-47,37 \%$, a w 2012 roku $-49,70 \%$. W latach 2008-2012 odnotowano więc trend wzrostowy w zakresie odsetka populacji $65+$ w ogólnej liczbie zachorowań na nowotwory hematologiczne (tab. 1). Największa liczba zachorowań na nowotwory hematologiczne w latach 2008-2012 dotyczyła białaczki limfatycznej (C91) - 7986, chłoniaków nie-Hodgkina niegrudkowych (C83) - 7558, szpiczaka plazmocytowego (C90) - 6270 oraz białaczki szpikowej (C92) - 5411 zachorowań [4]. Procentowy udział grupy wiekowej $65+$ w ogólnej zachorowalności na wymienione wyżej typy nowotworów hematologicznych w latach 2008-2012 przedstawiono na rycinie 1 .

\section{Postępy w leczeniu chorych na nowotwory hematologiczne powyżej 65. roku życia}

W ostatnich 20 latach dokonal się istotny postęp w diagnostyce i leczeniu nowotworów hematologicznych, a wprowadzenie nowych leków, takich jak przeciwciała monoklonalne, inhibitory kinaz tyrozynowych, inhibitory proteasomów, leki immunomodulujące i epigenetyczne, znacznie poprawiło skuteczność leczenia przy jednoczesnej dobrej ich tolerancji.

Chorzy w wieku $65+$ powinni mieć możliwość skorzystania $z$ nowoczesnych terapii, które skutkują 


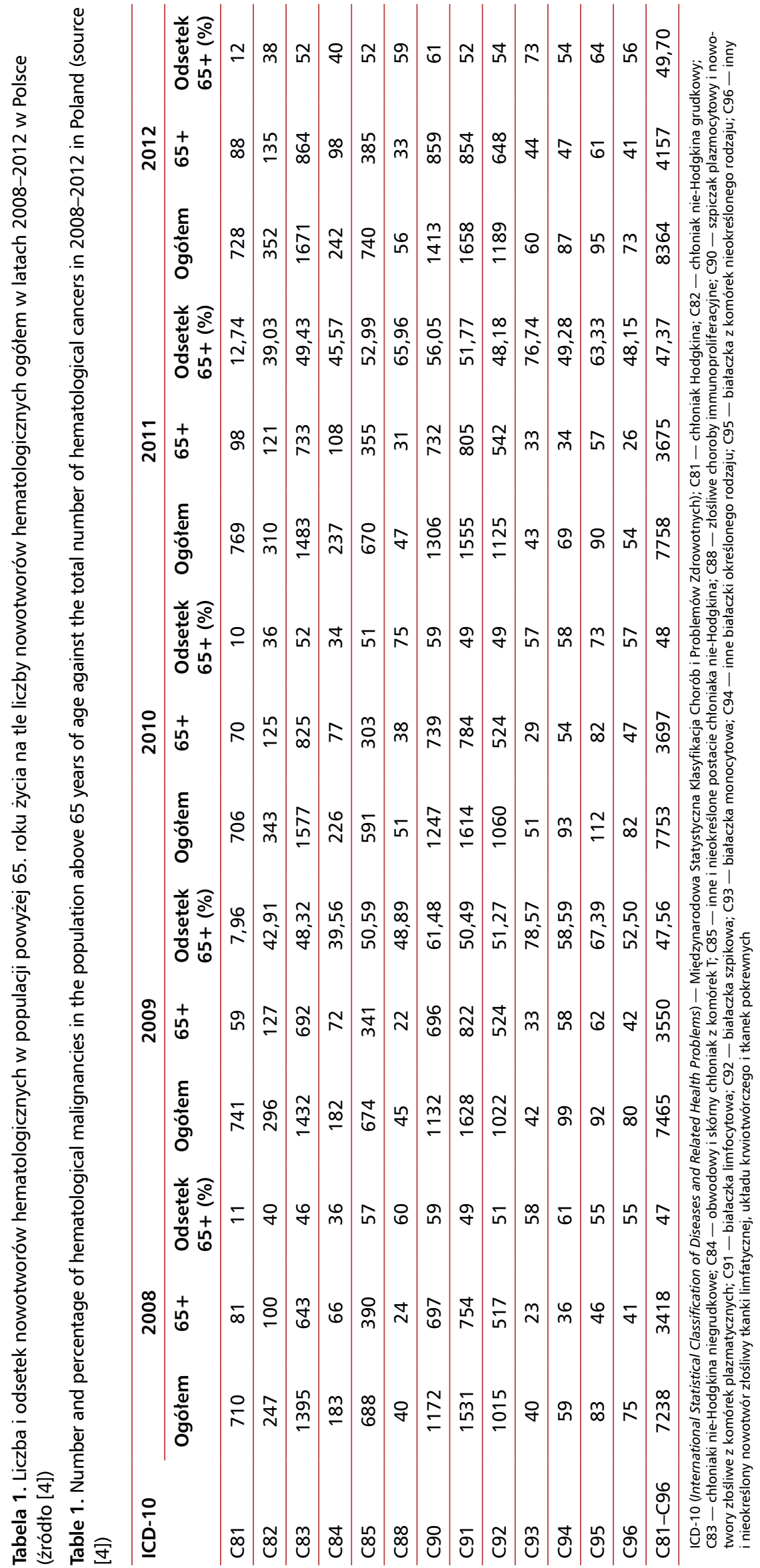




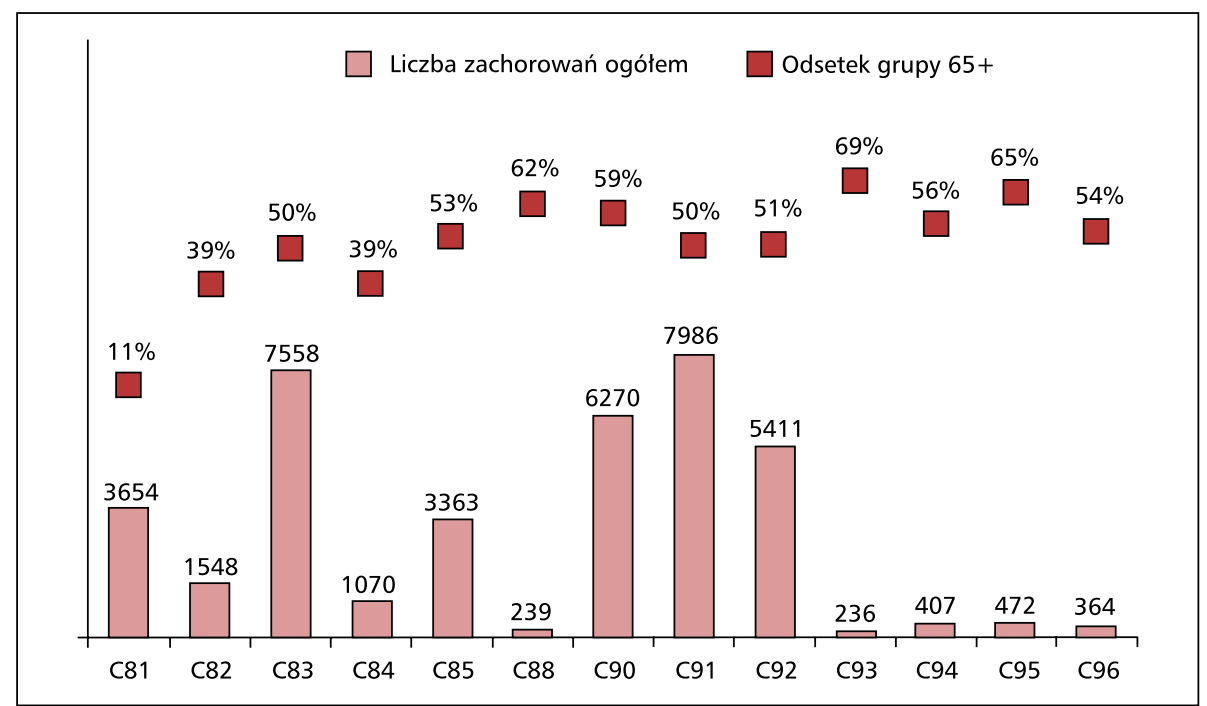

Rycina 1. Procentowy udział grupy wiekowej $65+$ w ogólnej zachorowalności na poszczególne typy nowotworów hematologicznych w latach 2008-2012 w Polsce (na podstawie [4]); C81 — chłoniak Hodgkina; C82 — chłoniak nie-Hodgkina grudkowy; C83 - chłoniaki nie-Hodgkina niegrudkowe; C84 — obwodowy i skórny chłoniak z komórek T; C85 — inne i nieokreślone postacie chłoniaka nie-Hodgkina; C88 - złośliwe choroby immunoproliferacyjne; C90 - szpiczak plazmocytowy i nowotwory złośliwe z komórek plazmatycznych; C91 — białaczka limfocytowa; C92 — białaczka szpikowa; C93 - białaczka monocytowa; C94 - inne białaczki określonego rodzaju; C95 — białaczka z komórek nieokreślonego rodzaju; C96 — inny i nieokreślony nowotwór złośliwy tkanki limfatycznej, układu krwiotwórczego i tkanek pokrewnych

Figure 1. Percentage of age group $65+$ in the overall incidence of various types of hematological malignancies in the years 2008-2012 in Poland (based on [4]); C81 — Hodgkin lymphoma; C82 - non-Hodgkin lymphoma, follicular; C83 - non-Hodgkin lymphomas, not follicular; C84 - peripheral and cutaneous T-cell lymphoma; C85 — other and unspecified forms of lymphoma, non-Hodgkin lymphoma; C88 - malignant immunoproliferative diseases; C90 - plasma cell myeloma and plasma cell malignancies; C91 - lymphocytic leukemia; C92 — myelogenous leukemia; C93 - monocytic leukemia; C94 — other specified type of leukemia; C95 - leukemia cell type undistinguished; C96 - different and indefinite malignant tumor of lymphoid, hematopoietic and related tissue

wydłużeniem przė̇ycia wolnego od progresji choroby i całkowitego przeżycia, a także poprawą jakości życia. Seniorzy z racji wieku, dodatkowego obciążenia współistniejącymi chorobami oraz zmniejszonej rezerwy funkcjonalnej narządów wymagają odrębnego postępowania i preferencji w zakresie dostępu do nowoczesnych technologii medycznych. Zastosowanie nowych leków u starszych chorych wymaga dokładnie zaprogramowanego leczenia wspomagającego oraz ustalenia właściwych dawek nowych leków, a także dobrania stosownej do wieku kombinacji tych leków i sekwencji ich stosowania. Wybór leczenia powinien uwzględniać osiągnięcie równowagi między skutecznością stosowanej terapii a jej toksycznością.

Obecnie brakuje ustalonych zaleceń i standardów dotyczących leczenia starszych chorych na nowotwory hematologiczne, ponieważ dotychczas jedynie pojedyncze badania kliniczne obejmowały tę populację chorych. Przy kwalifikacji do leczenia coraz powszechniej stosuje się inne niż wiek metrykalny kryteria służące ocenie ogólnego stanu chorego i wydolności poszczególnych narządów, uwzględniające tak zwaną całościową ocenę geriatryczną (CGA, Comprehensive Geriatric Assessment) [5]. Niezwykle istotnym aspektem leczenia starszych chorych jest uzyskanie poprawy jakości ich życia. Warunki socjalne i sytuacja rodzinna mogą mieć większe znaczenie w tej grupie pacjentów niż u chorych młodszych.

W ostatnich 5 latach nastąpił przełom w badaniach i wprowadzaniu na rynek medyczny nowoczesnych technologii medycznych. W latach 2010-2015 w Unii Europejskiej (UE) w dziedzinie hematologii onkologicznej zarejestrowano 18 technologii lekowych w 30 nowych wskazaniach rejestracyjnych [6]. Szczególowe zestawienie rejestracji Komisji Europejskiej w zakresie hematologii onkologicznej w latach 2010-2015, według liczby i nazw nowych molekuł oraz rodzaju wskazań 
Tabela 2. Szczegółowe zestawienie rejestracji Komisji Europejskiej w zakresie hematologii onkologicznej w latach 2010-2015 według liczby i nazw nowych molekuł oraz wskazań rejestracyjnych dotyczących leczenia chorych na określone nowotwory hematologiczne (na podstawie danych Komisji Europejskiej)

Table 2. Detailed registration data of the European Commission in the field of hematologic oncology in 2010-2015, according to the number of new molecules and registered indications in the treatment of patients with specific hematological malignancies (based on data from the European Commission)

\begin{tabular}{|c|c|}
\hline Molekuła & Wskazanie kliniczne \\
\hline Belinostat & PTCL \\
\hline Bendamustyna & $\begin{array}{l}\text { CLL } \\
\mathrm{NHL} \\
\text { PCM }\end{array}$ \\
\hline Bosutynib & CML \\
\hline Brentuksymab vedotin & $\begin{array}{l}\mathrm{HL} \\
\text { sALCL }\end{array}$ \\
\hline Carfilzomib & PCM \\
\hline Ibrutynib & $\begin{array}{l}\text { MCL } \\
\text { CLL } \\
\text { WM } \\
\text { FL } \\
\text { DLBCL }\end{array}$ \\
\hline Idelalisib & $\begin{array}{l}\mathrm{CLL} \\
\mathrm{FL}\end{array}$ \\
\hline Lenalidomid & MDS \\
\hline Mogamulizumab & PTCL \\
\hline Obinutuzumab & CLL \\
\hline Ofatumumab & CLL \\
\hline Panobinostat & PCM \\
\hline Piksantron & $\mathrm{NHL}$ \\
\hline Pomalidomid & PCM \\
\hline Ponatynib & $\begin{array}{l}\text { CML } \\
\text { ALL }\end{array}$ \\
\hline Rytuksymab & $\begin{array}{l}\text { NHL B-komórkowy } \\
\text { CLL } \\
\text { NHL }\end{array}$ \\
\hline Ruksolitynib & $\begin{array}{l}\text { PV } \\
\text { Mielofibroza }\end{array}$ \\
\hline Siltuksymab & $\begin{array}{l}\text { Wieloośrodkowa choroba } \\
\text { Castlemana }\end{array}$ \\
\hline \multicolumn{2}{|c|}{ 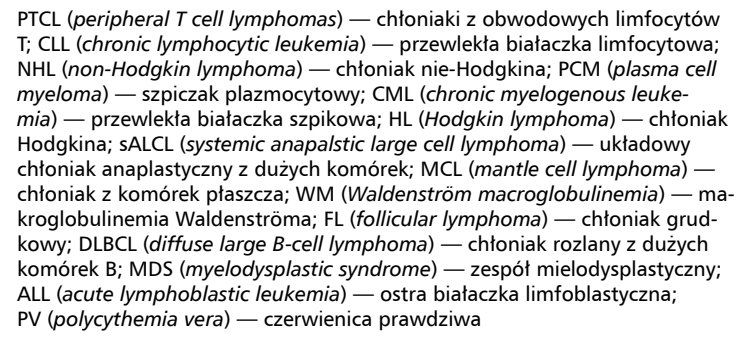 } \\
\hline
\end{tabular}

rejestracyjnych dotyczących leczenia chorych na określone nowotwory hematologiczne, przedstawiono w tabeli 2. Największą liczbę wskazań rejestracyjnych odnotowano w latach 2010-2015 w UE w zakresie chłoniaków (11 wskazań), przewlekłej białaczki limfocytowej (6), szpiczaka plazmocytowego (4) oraz przewlekłej białaczki szpikowej (2).

\section{Finansowanie nowoczesnych technologii w hematologii onkologicznej w Polsce}

W Polsce nowoczesne technologie lekowe stosowane w hematologii onkologicznej są obecnie dostępne w ramach programów lekowych (tab. 3) oraz $\mathrm{w}$ katalogu chemioterapii (anagrelid, azacytydyna, bendamustyna, bortezomib, imatynib, nelarabina, rytuksymab) [7].

W programach lekowych ściśle określono, jaka grupa chorych może skorzystać $z$ nowoczesnej terapii, a dzięki konieczności monitorowania skuteczności leczenia gwarantują prowadzenie terapii tylko u tych chorych, u których przynosi ona efekty. Ważne jest, aby tak zwane kryteria włączenia do programu lekowego oraz zasady monitorowania skuteczności i potencjalnej toksyczności leczenia były zgodne $z$ aktualnie obowiązującymi rekomendacjami odpowiednich towarzystw naukowych.

Różnice w dostępności do leczenia nowymi lekami (brak lub ograniczona refundacja) w poszczególnych krajach członkowskich UE wynikają przede wszystkim $z$ ograniczeń budżetowych [8]. W Polsce, mimo postępu w skuteczności leczenia nowotworów i wprowadzenia nowych leków, ciągle istnieje potrzeba lepszego wykorzystania sprzętu oraz doposażenia ośrodków onkologicznych w sprzęt do diagnostyki i leczenia nowotworów [9]. Ograniczona liczba chorujących na schorzenia onkohematologiczne oraz wprowadzone rozwiązania przez płatnika publicznego w Polsce w zakresie programów lekowych stwarzają realne szanse dostępu chorych do nowoczesnych leków w ramach standardów terapeutycznych. Należy również zaznaczyć, że w zakresie programów lekowych $\mathrm{w}$ onkohematologii $\mathrm{w}$ ostatnich latach poczyniono oszczędności, które warto byłoby przeznaczyć na nowe przełomowe terapie w nowotworach hematologicznych.

Według najnowszych danych opublikowanych przez Ministerstwo Zdrowia [10] w latach 2010-2014 odsetek wydatków Narodowego Funduszu Zdrowia (NFZ) na programy lekowe $z$ dziedziny onkohematologii na tle wydatków ogółem na programy onkologiczne i onkohematologiczne 
Hematologia 2015, tom 6, nr 3

Tabela 3. Aktualne programy lekowe stosowane w leczeniu chorych na nowotwory hematologiczne w Polsce (na podstawie danych Narodowego Funduszu Zdrowia [NFZ])

Table 3. Current drug programs applicable in the treatment of hematological malignancies in Poland (based on data from the National Health Fund [NFZ])

\begin{tabular}{ll}
\hline Nazwa programu lekowego NFZ & Substancje czynne \\
\hline „Leczenie chłoniaków złośliwych" & Rytuksymab \\
\hline "Leczenie przewlekłej białaczki szpikowej” & Dazatynib, nilotynib \\
\hline "Lenalidomid w leczeniu chorych na opornego lub nawrotowego szpiczaka mnogiego" & Lenalidomid \\
\hline „Leczenie dazatynibem ostrej białaczki limfoblastycznej z chromosomem Filadelfia (Ph+)" & Dazatynib \\
\hline "Leczenie beksarotenem ziarniniaka grzybiastego lub zespołu Sezary'ego" & Beksaroten \\
\hline
\end{tabular}

Tabela 4. Wartość oraz odsetek wydatków Narodowego Funduszu Zdrowia na programy lekowe z dziedziny onkohematologii na tle wydatków ogólem na programy onkologiczne i onkohematologiczne, w latach 2010-2014, w PLN (na podstawie danych $\mathrm{MZ}$ )

Table 4. The value and the percentage of the National Health Fund spending on drug programs in the field of onco-hematology against spending on oncology and onco-hematology in total, in 2010-2014, in PLN (based on data from the Ministry of Health)

\begin{tabular}{lccccc}
\hline Kategoria & $\mathbf{2 0 1 0}$ & $\mathbf{2 0 1 1}$ & $\mathbf{2 0 1 2}$ & $\mathbf{2 0 1 3}$ & $\mathbf{2 0 1 4}$ \\
\hline $\begin{array}{l}\text { Wydatki ogółem na programy onkolo- } \\
\text { giczne i onkohematologiczne (PLN) }\end{array}$ & 520278065 & 589559377 & $\mathbf{7 5 8 7 4 5 9 1 5}$ & 923509653 & 1111805147 \\
\hline $\begin{array}{l}\text { Wydatki na programy } \\
\text { onkohematologiczne (PLN) }\end{array}$ & 223419077 & 241205012 & 286083506 & 349650505 & 372101671 \\
\hline $\begin{array}{l}\text { Odsetek programów onkohematolo- } \\
\text { gicznych (\%) }\end{array}$ & 42,94 & 40,91 & 37,70 & 37,86 & 33,47 \\
\hline
\end{tabular}

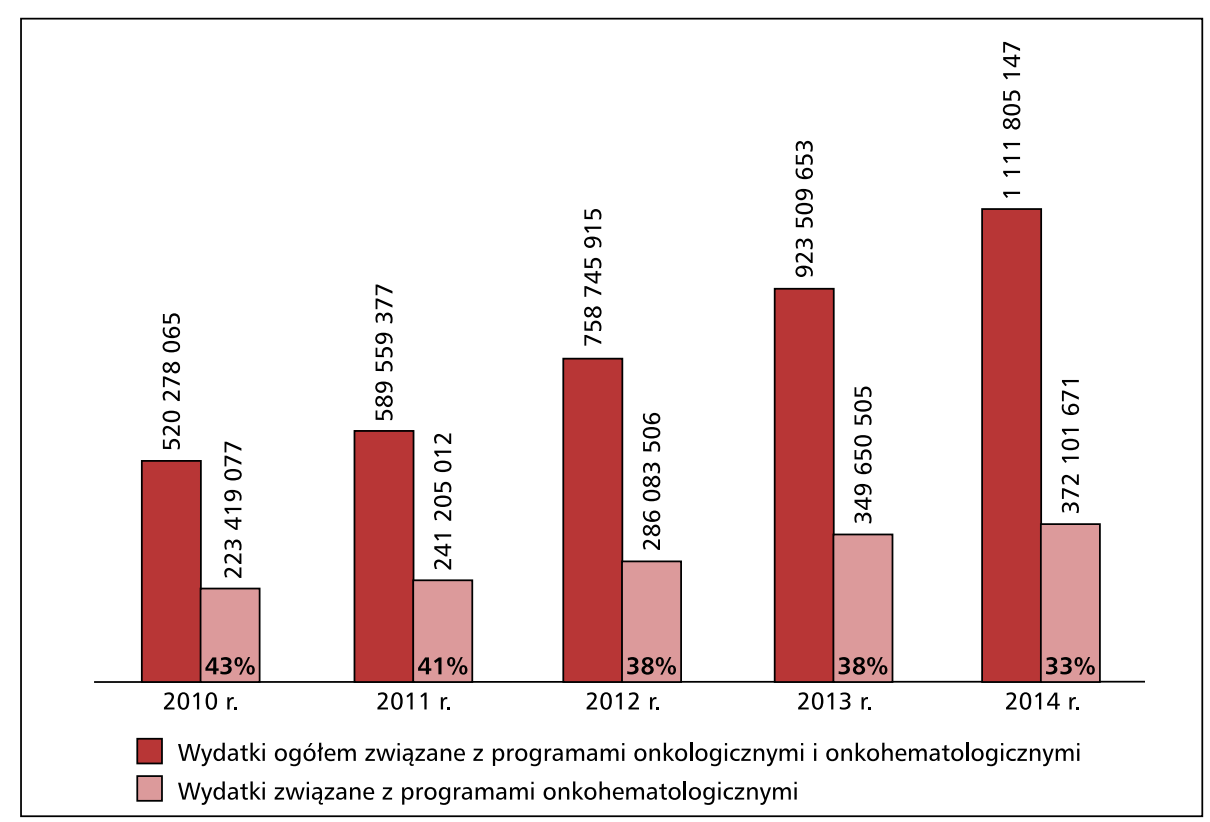

Rycina 2. Wartości oraz odsetek wydatków Narodowego Funduszu Zdrowia na programy lekowe z dziedziny onkohematologii na tle wydatków ogółem na programy onkologiczne i onkohematologiczne w latach 2010-2014 w PLN (na podstawie danych $\mathrm{MZ}$ )

Figure 2. The value and the percentage of the National Health Fund spending on drug programs in the field of onco-hematology against spending on oncology and onco-hematology in total, in 2010-2014 in PLN (based on data from the Ministry of Health) 
uległ zmniejszeniu. W 2010 roku wynosił 42,94\%, w 2011 roku - 40,91\%, w 2012 roku - 37,70\%, w 2013 roku $-37,86 \%$, a w 2014 roku $-33,47 \%$ nakładów NFZ na programy onkologiczne i onkohematologiczne ogólem (tab. 4, ryc. 2).

\section{Wyzwania systemowe w hematologii onkologicznej}

System ochrony zdrowia w Polsce wymaga zmian prowadzących do jego optymalizacji. Dodatkowymi czynnikami stymulującymi wprowadzanie koniecznych zmian są starzenie się populacji i zwiększenie zachorowalności na nowotwory, $\mathrm{w}$ tym nowotwory hematologiczne. W zakresie hematoonkologii, ze względu na epidemiologiczną skalę problemu, można byłoby zbudować efektywny system modelowy będący inspiracją do dalszych działań w leczeniu chorych na nowotwory, a - być może - dla całego systemu ochrony zdrowia. Należy dążyć do wprowadzenia zmian w finansowaniu świadczeń hematologicznych, a w szczególności objąć nielimitowanym finansowaniem wszystkie świadczenia $z$ zakresu onkohematologii oraz zlikwidować stawkę degresywną w wybranych schorzeniach onkohematologicznych. Nowoczesne technologie medyczne powinny być jednym z elementów wydolnego i sprawnego systemu opieki onkohematologicznej, w którym podmiotem będzie leczona osoba i jej potrzeby zdrowotne, a istotą - uzyskanie maksymalnej skuteczności terapii przeciwnowotworowej przy zachowaniu bezpieczeństwa realizacji procedur potencjalnie zagrażających życiu pacjenta [11].

W celu poprawy skuteczności i efektywności leczenia Polskie Towarzystwo Hematologów i Transfuzjologów we wspólpracy z Krajową Radą ds. Onkologii i Instytutem Hematologii i Transfuzjologii, a w przyszłości - Narodowym Instytutem Onkologii i Hematologii powinno opracować projekty wytycznych i algorytmów postępowania w onkohematologii [12]. Aby poprawić jakość udzielanych świadczeń, w powiązaniu $z$ optymalnym wykorzystaniem zasobów $\mathrm{w}$ hematologii, należy wprowadzić trzy poziomy referencyjności dla podmiotów leczniczych udzielających świadczeń $z$ zakresu hematologii na podstawie kryteriów określonych $\mathrm{w}$ rozporządzeniu ministra zdrowia [13]. W związku z planowanym przez ministra zdrowia procesem tworzenia map potrzeb zdrowotnych należy opracować projekt Krajowej Sieci Hematologicznej opartej na danych epidemiologicznych, zasobach lekarzy hematologów i podmiotów leczniczych $z$ uwzględnieniem ich poziomów referencyjności w zakresie hematologii. W celu zapewnienia odpowiedniej liczby hematologów hematologia, podobnie jak onkologia kliniczna, powinna być zaliczona do tak zwanych specjalności deficytowych, a kształcenie w dziedzinie hematologii powinno być prowadzone przez Centrum Medyczne Kształcenia Podyplomowego we współpracy $z$ Narodowym Instytutem Onkologii i Hematologii $[12,14]$.

\section{Podsumowanie}

Autorzy niniejszej pracy rekomendują, aby $\mathrm{w}$ wyniku konsensusu między interesariuszami systemowymi wypracować model nowoczesnej opieki onkohematologicznej dla wszystkich chorych, biorąc pod uwagę specyfikę nowotworów hematologicznych i potrzeby terapeutyczne coraz liczniejszej populacji osób powyżej 65. roku życia w Polsce.

\section{Piśmiennictwo}

1. Prognoza ludności na lata 2014-2050, GUS, 2014. Dostępne na: http://stat.gov.pl/obszary-tematyczne/ludnosc/prognoza-ludnosci/ /prognoza-ludnosci-na-lata-2014-2050-opracowana-2014-r-,1,5. html. Data dostępu: 11.08.2015 r.

2. Wojciechowska U., Ditkowska J,, Zatoński W. Nowotwory złośliwe w Polsce w 2012 r. Centrum Onkologii. Krajowy Rejestr Nowotworów. Ministerstwo Zdrowia. Warszawa 2014. Dostępne na: http://onkologia.org.pl/wp-content/uploads/Biul2012net.pdf. Data dostępu: 2.08.2015 r.

3. Ditkowska J., Wojciechowska U., Zatoński W. Prognozy zachorowalności i umieralności na nowotwory złośliwe do $2025 \mathrm{r}$. Centrum Onkologii. KRN, 2009. Dostępne na: http://onkologia. org.pl/wp-content/uploads/Prognozy_2025.pdf Data dostępu: 25.08.2015 r.

4. Krajowy Rejestr Nowotworów. Dostępne na: http://onkologia.org. pl/raporty/\#tabela_nowotwor_wg_wieku Data dostępu: $2.08 .2015 \mathrm{r}$.

5. Czyż A. Postępy w leczeniu wspomagającym u chorych na nowotwory układów chłonnego i krwiotwórczego Hematologia 2015; 6: 77-84.

6. Pharmaceuticals - community register. European Commission. Dostępne na: http://ec.europa.eu/health/documents/community-register/html/register.htm Data dostępu: 20.08.2015 r.

7. Lista leków refundowanych — obwieszczenia Ministra Zdrowia. Dostępne: http://www.mz.gov.pl/leki/refundacja/lista-lekow-refundowanych-obwieszczenia-ministra-zdrowia. Ministerstwo Zdrowia. Data dostępu: 28.10.2015.

8. Developments in cancer treatments, market dynamics, patient access and value. Global Oncology Trend Report 2015. IMS Institute for Healthcare Informatics, 2015. Dostępne na: www.theinsinstitute.org. Data dostępu: 26.07.2015 r.

9. Zachorowalność i umieralność na nowotwory a sytuacja demograficzna Polski. Rządowa Rada Ludnościowa, GUS, 2014. Dostępne na: http://bip.stat.gov.pl/organizacja-statystyki-publicznej/rzadowa-rada-ludnosciowa/publikacje-rzadowej-rady-ludnosciowej. Data dostępu: 25.08.2015 r. 
10. Radziewicz-Winnicki I. Odpowiedź ministra zdrowia na wystąienie Fundacji Onkologicznej Osób Młodych Alivia. Ministerstwo Zdrowia 2015: 29. Dostępne na: http://www.mz.gov.pl/leki/refundacja/komunikaty-dotyczace-listy-lekow-refundowanych. Data dostępu: 23.07.2015 r.

11. Warzocha K. Koncepcje zmian systemowych w opiece onkologicznej w Polsce u progu 2015 roku. Hematologia 2014; 5: 179-192.
12. Warzocha K. Narodowy Instytut Onkologii i Hematologii. Hematologia 2013; 4: 185-196.

13. Warzocha K. Krajowa sieć onkologiczna. Hematologia 2014; 5: 1-21.

14. Gałązka-Sobotka M., Lech-Marańda E., Warzocha K. i wsp. Raport „Hematologia onkologiczna — aspekty kliniczne, ekonomiczne i systemowe”. IZWOZ Uczelnia Łazarskiego, Warszawa 2015 . 